\title{
Pembangunan Partisipasi Politik Generasi Muda melalui Website dan Twitter Jejak Parlemen
}

\author{
Imaddudin $^{\mathrm{a}, 1,{ }^{*} \text { dan Tri Susanto }} \mathrm{o}^{\mathrm{b}, 2}$ \\ Universitas Bhayangkara Jakarta Raya ${ }^{a}$ dan Universitas Singaperbangsa Karawang ${ }^{b}$ \\ Email: ${ }^{1}$ imaddudin@dsn.ubharajaya.ac.id", ${ }^{2}$ tri.susanto@staff.unsika.ac.id \\ *corresponding author
}

\author{
Keywords: \\ Development Communication, \\ Political Education, Trail of \\ Parliament, wikiDPR.
}

\begin{abstract}
The Development of political participation in the younger generation is often done now, as the population dominates among other generations. Knowledge about politics has begun to be introduced by various parties both government, private or other organizations. This is in line with the Parliamentary Footprint organization which was formed to provide information and knowledge as well as to eliminate anxiety that has not been recorded from the footsteps of MPs, besides building a more mature democratic system in the coming legislative election year. This study aims to determine the role of volunteers through political education agents in the participation of young people in the digital age. In addition, this study also aims to determine the impact of the Parliamentary Footprint as an agent of youth political education in building political participation. This research approach uses descriptive qualitative methods with data acquisition through interviews, observations, and literature studies that are relevant to the research problem. The results showed that the younger generation is still optimistic in responding to the political world, seen from the voluntary movement that is still running until now, and the number of active volunteers continues to increase in each generation until now. Researchers suggest the need to intensify the implementation of political socialization to the younger generation. The need for the government and other stakeholders to optimize the role of each political education agent as part of partners for the implementation of political education in the country. In addition, the need for younger generations who are given more opportunities and broader responsibilities in the public sphere to be part of the country's political journey as well as being involved as members of political parties, or other social political organizations.
\end{abstract}

\begin{abstract}
ABSTRAK
Pembangunan partisipasi politik pada generasi muda saat ini kerap dilakukan, seiring jumlah populasinya yang mendominasi di antara generasi lainnya. Pengetahuan terhadap politik sudah mulai diperkenalkan oleh berbagai pihak baik pemerintah, swasta maupun organisasi lainnya. Hal ini sejalan dengan organisasi Jejak Parlemen yang dibentuk untuk memberikan informasi dan pengetahuan serta menghilangkan kegelisahan yang selama ini tidak terekam dari para jejak anggota parlemen, selain itu membangun sistem demokrasi yang lebih matang di tahun pemilihan anggota legislatif kedepan. Penelitian ini bertujuan untuk mengetahui peran relawan melalui agen pendidikan politik dalam partisipasi generasi muda di era digital. Selain itu, penelitian ini juga bertujuan untuk mengetahui dampak Jejak Parlemen sebagai agen pendidikan politik generasi muda dalam membangun partisipasi politik. Pendekatan penelitian ini melalui metode kualitatif deskriptif dengan perolehan data melalui wawancara, observasi, dan studi literatur yang relevan dengan permasalahan penelitian. Hasil penelitian menunjukkan generasi muda masih optimis dalam menyikapi dunia politik, terlihat dari gerakan relawan yang masih berjalan sampai saat ini, serta jumlah relawan yang aktif terus bertambah di tiap
\end{abstract}


angkatannya sampai saat ini. Peneliti menyarankan perlunya mengintensifkan pelaksanaan sosialisasi politik kepada generasi muda. Perlunya bagi pemerintah dan stakeholder lainnya mengoptimalkan peran-peran dari setiap agen pendidikan politik sebagai bagian dari mitra bagi pelaksanaan pendidikan

Kata Kunci:

Komunikasi Pembangunan,

Pendidikan Politik, Jejak

Parlemen, wikiDPR. politik di negeri ini. Selain itu, perlunya generasi muda yang lebih diberikan kesempatan serta tanggung jawab yang lebih luas dalam ruang publik untuk menjadi bagian dari perjalanan politik negeri ini seperti halnya dilibatkan sebagai anggota dari partai politik, ataupun organisasi sosial politik lainnya.

Copyright (C) 2020 Channel Jurnal Komunikasi. All right reserved.

\section{PENDAHULUAN}

Partisipasi generasi muda dalam bidang politik Indonesia masih minim terlihat banyak generasi muda yang tidak tertarik karena generasi muda banyak menganggap bahwa suara mereka tidak didengar, politik adalah dunia korupsi. Dari analisis Orb Media terhadap survei terhadap kepada 979 ribu orang di 128 negara yang dilakukan pada tahun 19802018, ditemukan bahwa anak-anak muda yang peduli pada pemerintahan cenderung lebih menolak terlibat dalam politik praktis. Bahkan untuk memberikan suara pun mereka enggan atau memilih pasif dan lebih memilih mengadakan protesprotes di jalanan dalam bentuk demonstrasi. Kesimpulan itu tercermin dari segi usia menyatakan: 9-17\% orang-orang yang berusia dibawah 40 tahun punya kecenderungan berdemonstrasi ketimbang mereka yang di atas 40 tahun. Hasil itu menunjukkan ironis yang cukup tinggi dengan kondisi pada awal di tahun 2000 -an. Saat itu, hanya 3\% kecenderungan orang-orang berusia di bawah 40 tahun untuk menjalankan protes jalanan dibandingkan mereka yang berusia di atas 40 tahun. (Investigasi.tempo.co/generasi-muda-dan-politik)

Dari keprihatinan itu beberapa generasi muda menginisiasi sebuah gerakan yang meningkatkan partisipasi politik melalui gerakan sosial dan komunitas salah satu gerakan tersebut adalah wikiDPR atau yang saat ini berubah menjadi Jejak Parlemen sebuah organisasi yang digagas oleh sekelompok anak muda yang merasa kekurangan mendapatkan informasi terkait pemilihan umum tahun 2014 lalu, sehingga mengalami kebingungan siapa calon anggota legislatif atau wakil rakyat yang layak mewakili. Dimana minimnya informasi mengenai banyaknya calon legislatif atau calon wakil rakyat yang saat itu mencalonkan, dan cenderung hanya menampilkan biografi yang sangat mendasar. Tujuan pendirian wikiDPR nama akun saat itu adalah mengembangkan transparansi di lingkungan parlemen dan menyediakan basis data seputar wakil rakyat bagi masyarakat. Harapannya rakyat mampu memilih secara rasional dengan melihat rekam jejak para petahana yang tercatat dengan baik, terutama secara digital.

Jejak Parlemen melalui website dan media sosial lainnya seperti twitter menginformasikan dan mengajak generasi muda khususnya mahasiswa untuk bergabung menjadi relawan, merasakan, memahami, memantau dan mempelajari kinerja DPR RI atau wakil rakyatnya dalam menjalankan tugasnya. Relawan yang terdiri dari mahasiswa berasal dari Perguruan tinggi baik negeri maupun swasta ini diseleksi dan dilatih sebelum bertugas di senayan. Penggunaan media sosial twitter Jejak Parlemen sebagai saluran dalam menyebarkan informasi baik tentang hasil rapat ataupun kebijakan yang dibutuhkan oleh masyarakat

Dari latar belakang diatas maka penulis ingin melihat bagaimana peran Jejak Parlemen dalam mendorong partisipasi politik generasi muda dan penggunaan media sosial sebagai sarana informasi yang membangun pendidikan politik terhadap generasi.

\section{TINJAUAN PUSTAKA DAN KERANGKA PEMIKIRAN}

Tujuan komunikasi pembangunan ialah untuk membangun pola pikir agar berpikir panjang kedepan untuk meningkatkan dan memajukan secara budaya, sosial, ekonomi dan politik serta teknologi, baik yang terbangun secara tradisional maupun melalui teknologi dalam penyampaian ide dan gagasan yang selayaknya diterapkan oleh generasi muda untuk merangsang dan memotivasi untuk mencapai suatu perubahan.

Menerapkan model Teori Sanders (dalam Harun dan Ardianto, 2017:33) dimana menganalisis suatu pembangunan dalam masyarakat, kita bisa melihat suatu komunikasi dari empat perspektif atau pandangan dimana komunikasi sebagai proses, suatu metode, program maupun suatu gerakan sosial.

Agar pencapaian komunikasi pembangunan lebih tepat pada sasarannya dapat dengan cara menghindari beberapa kemungkinan-kemungkinan yang bisa berdampak dari hal yang tidak diharapkan, tentunya dengan pertimbangan beberapa hal yang tengah menjadi sorotan. Menurut Rogers dan Adhikarya (dalam Harun dan Ardianto, 2017:163) efek kesenjangan bisa diperkecil jika strategi komunikasi pembangunan dapat dirumuskan melalui prinsip-prinsip sebagai berikut:

1. Penggunaan pada pesan yang dirancang secara khusus (tailored message) ditujukan pada khalayak yang spesifik atau pada suatu komunitas tertentu. 
2. Pendekatan ceiling effect, diartikan dengan mengkomunikasikan suatu pesan untuk golongan atau komunitas yang tidak dituju, katakanlah golongan atas, merupakan "redundansi" (tidak seperti itu karena sudah dilewati atau dilakukan oleh mereka) atau kecil manfaatnya bagi golongan yang tertuju. Akan tetapi tetap memiliki manfaat bagi golongan atau khalayak yang hendak dijangkau.

3. Pendekatan narrow casting, diartikan menempatkan penyampaian suatu pesan yang ditujukan terhadap kepentingan khalayak. Lokalisasi disini berarti penyampaian informasinya disesuaikan dengan situasi khalayak berada.

4. Pemanfaatan pada saluran tradisional, dimana saluran yang biasa digunakan oleh pihak atau daerah setempat menyesuaikan dengan kebiasaan serta budayanya, seperti pertunjukan rakyat yang menyampaikan pesan-pesan kehidupan sesuai dengan perkembangan yang berlangsung di daerah setempat.

5. Pengenalan para tokoh masyarakat atau pemimpin opini dalam suatu wilayah masyarakat yang mereka percayai dan meminta bantuan ide serta gagasan dalam membantu mengkomunikasikan pesan-pesan pembangunan.

6. Keaktifkan para agen-agen perubahan yang berasal dari kalangan masyarakat setempat sebagai pihak yang membangun dan beroperasi di kalangan rekan sejawat mereka sendiri.

7. Mekanisme keikutsertaan khalayak dengan memberikan pemahaman penyampaian pesan-pesan komunikasi pembangunan yang tepat dan benar dari awal hingga evaluasi akhir.

\section{A. Strategi Komunikasi}

Pesan-pesan pembangunan yang tersusun baik dalam sebuah perencanaan merupakan cara untuk mencapai suksesnya kampanye. Jika tujuan kampanye untuk mengubah perilaku individu dan mengubah kebijakan publik maka perlu adanya penetapan strategi dari hulu ke hilir untuk diterapkan dalam praktiknya. Strategi yang terstruktur baik diharapkan mampu memberikan perubahan sesuai dengan tujuan yang ingin dicapai. Sebuah kampanye secara sederhana berisikan rancangan yang terdiri dari taktik untuk bisa dikomunikasikan kepada sasarannya dalam hal ini publik.

Sedangkan menurut Onong Uchjana (Onong, 1989:35) mengenai Strategi komunikasi adalah paduan antara perencanaan komunikasi (Communication Planning) dengan manajemen komunikasi (Communication Management) untuk mencapai tujuan yang diinginkan. Setiap strategi komunikasi itu berbeda pendekatannya melihat dari situasi dan kondisi yang sedang berlangsung disertai dengan perencanaan guna melancarkan komunikasi pembangunan.

Rogers (1981:37) mengatakan, komunikasi tetap dianggap sebagai perpanjangan tangan para perencana pemerintah dan fungsi utamanya adalah untuk mendapatkan dukungan masyarakat dan partisipasi mereka dalam pelaksanaan rencanarencana pembangunan. Artinya peranan pemerintah atau agen pembangunan perlu memperhatikan strategi komunikasi dalam menyampaikan pesan yang efektif dan sesuai harapan dan tujuan.

\section{B. New Media}

New Media dalam buku Marketing Management: Philip Kotler dan Kevin Keller (Kotler, 2012:568) media sosial menyampaikan informasinya melalui teks, gambar, dan suara dengan pengguna lainnya baik secara individu maupun organisasi/perusahaan.

Berbagai bidang sosial, ekonomi, budaya, pendidikan dan teknologi akan berkembangan dengan publisitas dan pengaplikasian internet secara baik, tak luput dengan bidan politik yang membutuhkan publisitas dalam menginformasikan segala misi, kebijakan dan praktiknya baik melalui media konvensional maupun media baru berteknologi. Media internet digunakan secara paralel dalam praktik politik baik secara individu maupun kelembagaannya, menganggap semua media potensial dalam menarik simpatik untuk peningkatan popularitas para tokohnya atau partai politiknya.

Menurut Saqib Riaz terkait dengan Komunikasi politik melalui media baik digunakan secara perorangan maupun organisasi/lembaga merupakan cara untuk mendapatkan dukungan pada saat pemilihan umum atau juga diluar pemilihan umum yang berlangsung (Riaz, 2010:2)

Diharapkan internet menjadi sarana dalam menunjukan segala kebijakan dan memperkenalkan tokoh ataupun partai ke ranah publik agar lebih dikenal dan dijangkau oleh semua masyarakat untuk menarik simpatisan, dukungan serta penentuan pilihan.

\section{Partisipasi Politik}

Menurut Miriam Budiardjo (2008:367), berpartisipasi secara aktif terhadap politik merupakan aktivitas seseorang atau sekelompok orang untuk menuju jalan secara langsung dan tidak langsung memperkenalkan diri dan kebijakan secara persuasif kepada khalayak sasarannya. Partisipasi politik bisa melalui pemilihan umum dengan memberikan suara, aktif dalam kegiatan politik lainnya, menjaga relasi serta lobbying dengan pihak-pihak yang berperan langsung/sesama partisipan politik lainnya, baik menjadi anggota suatu partai atau gerakan sosial lainnya. 
Berikut bentuk partisipasi politik menurut Colin Mc Andrews dan Mochtar Mas'oed (1978:42-43), yaitu:

1. Partisipasi politik secara Konvensional melalui beberapa hal diantaranya, memberikan suara dalam pemilihan umum, berkampanye dan diskusi politik, tergabung dalam suatu organisasi politik, berkomunikasi secara persuasif kepada pihak-pihak yang berkaitan dengan politik.

2. Partisipasi Politik secara Non-Konvensional melalui pengajuan petisi secara Demonstrasi, tindakan mogok serta tindakan-tindakan yang merusak dan membahayakan baik kekerasan secara politik individu maupun organisasi.

Bentuk partisipasi politik secara Konvensional dianggap sebagai bentuk partisipasi yang "Normal” dalam sistem demokrasi modern, namun partisipasi politik secara Nonkonvensional dianggap legal maupun ilegal yang penuh dengan kekerasan dan revolusioner. Dasar adanya partisipasi politik merupakan bentuk kesadaran setiap orang tanpa adanya paksaan, ancaman maupun pengerahan dari oknum atau pihak tertentu. Partisipasi politik muncul atas kehendak pribadi bukan dari dorongan yang dimobilisasi untuk mencapai tujuan tertentu.

Aspek-Aspek Penentu Partisipasi Politik menurut Mochtar Mas'oed \& Colin Mac Andrews, (1978: 46-47), yaitu :

1. Pendidikan tinggi mempengaruhi keaktifan seseorang terhadap persoalan-persoalan politik yang sedang berkembang dengan kecakapan menganalisa, menciptakan minat serta kemampuan berpolitik. Keputusan pemilih (electorate) untuk berpartisipasi politik dipengaruhi oleh aktivitas kampanye politik. Pada umumnya kampanye politik hanya mampu menjangkau partisipan setiap partai yang terus memberikan suara dan mendukung kebijakan politik.

2. Aspek penghambat (alasan) seseorang tidak berpartisipasi dalam kehidupan politik. Tiga alasan yang dikemukakan oleh Morris Rosenberg terhadap seseorang yang tidak mau berpartisipasi politik. Pertama, Ketakutan akan konsekuensi negatif dari aktivitas politik, bahwa berpartisipasi politik merupakan ancaman bagi kehidupan. Kedua, berpartisipasi politik adalah kesia-siaan yang tidak akan mempengaruhi proses politik. Ketiga, tidak adanya pemicu untuk meningkatkan partisipasi politik yang tidak dihargai baik ide dan gagasannya.

Tinjauan pustaka dan latar belakang penelitian ini bertujuan untuk mengetahui peran agen pendidikan politik dalam partisipasi generasi muda di era digital. Selain itu, penelitian ini mengetahui dampak keberadaan Jejak Parlemen sebagai agen perubahan melalui pendidikan politik generasi muda dalam berpartisipasi secara politik.

\section{METODE PENELITIAN}

Metode pada penelitian ini secara kualitatif deskriptif yang memaparkan bagaimana jejak parlemen terbentuk dan proses para relawan politik menyampaikan informasi terkait dengan perkembangan para perwakilan rakyat.

Pendekatan kualitatif menurut Bogdan dan Taylor (dalam buku Moleong, 2000:3), bahwa pendekatan kualitatif merupakan prosedur penelitian berupa data deskriptif terdiri dari kata-kata secara tertulis atau lisan orang-orang dan perilaku yang dapat diamati, pendekatan ini diarahkan pada latar dan individu secara holistik (utuh).

Kurang lebih selama tiga bulan penelitian ini berlangsung, dalam teknik pengumpulan datanya melalui wawancara kepada co-founder jejak parlemen, observasi dan pengumpulan dokumen lainnya yang relevan terhadap penelitian. Penelitian ini menggunakan teknik analisis data secara kualitatif dengan mereduksi data, menyajikan data, sampai menarik kesimpulan (Miles dan Huberman, 1992:20).

Informasi tersajikan mengenai partisipasi politik generasi muda dalam gerakan melalui komunikasi digital pada website dan twitter jejak parlemen dalam memberikan informasi mengenai kegiatan di yang terjadi di DPR RI.

\section{HASIL PENELITIAN}

Jejak parlemen merupakan suatu organisasi yang dibentuk oleh beberapa anak muda yang merasa bimbang pada masa pemilihan umum legislatif di tahun 2014 lalu. Informasi mengenai calon-calon anggota legislatif yang bersaing sangatlah minim, dan cenderung hanya biografi mendasar. Sedangkan, calon petahana tidak ada keterangan atau informasi mengenai rekam jejak tentang kinerja mereka selama 5 tahun mewakili rakyat di kursi DPR. Akun media sosial jejak parlemen dibuat untuk menjawab kegundahan dengan harapan dapat membangun pemahaman akan sistem demokrasi yang lebih siap dan matang di tahun pemilihan anggota legislatif tahun 2019 dan di tahun berikutnya. Selain itu, Misi nya untuk mempersiapkan masyarakat Indonesia melalui data yang komprehensif terkait rekam jejak seorang anggota legislatif saat menjabat mewakili rakyat dari tahun 2014-2019. Tim Jejak parlemen yang berada di DPR bertugas untuk meliput, merekam dan menyebarkan melalui media sosial jejak parlemen. Sejalan pernyataan Indah Hayati selaku Co Founder Jejak Parlemen "Kami menyebarkan informasi secara langsung dan lengkap (dari awal rapat dibuka, sampai ditutup) melalui Twitter dan kami merangkum rapat tersebut dan dipublikasi melalui website kami”. (Indah Hayati, wawancara, 25 November 2019). 
Jejak Parlemen melalui liputan, rekaman tersebut memastikan semua anggota legislatif yang hadir dan menyampaikan pendapat mereka saat rapat dengan pemerintah/instansi yang bersangkutan tersampaikan pendapatnya dengan jelas, sehingga kebijakan yang akan terlahir pun bisa menjadi transparansi untuk masyarakat. Dari peliputan, Jejak Parlemen juga menuliskan rangkuman untuk masing-masing rapat dan melakukan update informasi profil-profil anggota DPR.

Tujuan pendirian Jejak Parlemen adalah mengembangkan transparansi di lingkungan parlemen dan menyediakan basis data seputar wakil rakyat bagi masyarakat. Diharapkan, saat pemilu nanti, rakyat bisa memilih lebih rasional karena rekam jejak para petahana tercatat dengan baik, terutama di dunia digital. Melalui akun media sosial twitter jejak parlemen @WikiDPR memaparkan hasil kerja relawan terkait kinerja para anggota parlemen bisa selalu terpantau publik. Akun Jejak Parlemen@WikiDPR, yang kini memiliki 35,1 ribu pengikut, merupakan akun utama berisi informasi umum terkait agenda dan kinerja parlemen dalam sehari. Akun tersebut memuat tautan rangkuman kegiatan serta kebijakan DPR.

Akun jejak parlemen dengan nama dahulu@WikiDPR memiliki akun-akun turunan. Ada akun@WikiDPR1 yang juga (real time) melaporkan jalannya rapat di komisi I, II, III, Badan Legislasi, serta rapat paripurna lewat kicauan langsung. Selain itu akun@WikiDPR2 secara khusus mengulas mengenai rapat di komisi IV, V, VI, VII, dan XI, serta Badan Anggaran. Adapun akun@WikiDPR3 untuk kicauan rapat di komisi VIII, IX, dan X. Tak hanya melalui Twitter. Jejak parlemen juga memiliki situs website wikidpr.org. Situs ini menyajikan hasil kegiatan parlemen yang lebih lengkap daripada yang diunggah di Twitter. Melalui sekali klik, masyarakat bisa mencari anggota DPR berdasarkan daerah pemilihannya. Laman berikutnya akan memunculkan informasi detail mengenai wakil rakyat yang diinginkan. Tidak hanya biodata keanggotaan partai, latar belakang pendidikan serta profesi, tetapi juga sikap dan kebijakan politik terkait dengan isu dan topik.

Para relawan dengan sukarelawan meliput, mengumpulkan informasi dan memberikan informasi tanpa bayaran sepeserpun. Meski demikian, hal itu tidak menyurutkan semangat mereka. Mahasiswa tidak hanya sekedar menjadi relawan tetapi bisa ikut partisipasi dalam pengembangan diri. Menurut Co Founder jejak parlemen Indah Hayati menanggapi generasi muda sangat penting untuk memahami politik untuk tidak hanya kritis, namun aktif dalam membangun curiosity tentang politik di negeri sendiri. Sehingga pengertian generasi muda mengenai politik bisa menjadi sangat dalam, sehingga saat mereka memberikan kritik kepada orang-orang yang berkuasa kritik tersebut memiliki bobot yang tidak bisa dipungkiri ataupun diabaikan (Indah Hayati, wawancara, 25 November 2019).

Mayoritas relawan berasal dari kalangan mahasiswa/i sejumlah perguruan tinggi di Jakarta atau Jabodetabek yang tetap militan. Saat berlangsungnya rapat Komisi II DPR dengan Komisi Pemilihan Umum dan Kementerian Dalam Negeri, pada bulan Agustus hingga September 2016, Kompas melihat para anggota legislatif atau parlemen betah mengikuti rapat-rapat secara maraton hingga dini. Tak sebatas itu, mereka juga rajin meminta dokumen yang sedang dibahas atau sudah disahkan di DPR serta absensi anggota DPR ke sekretariat DPR saat Rapat Paripurna DPR. Saat rapat paripurna berlangsung, para relawan melaporkan kondisi rapat sekaligus aspirasi dan kebijakan yang didiskusikan, sampai peserta yang tergabung pun turut menjadi perhatian untuk diketahui. Hasil hitungannya berbeda dengan formulir absen Sekretariat Jenderal DPR. Wajar saja, budaya titip-menitip absen anggota DPR belum juga pupus.

Para relawan tersebut digerakkan untuk menyampaikan aspirasi dan kebijakan, serta kinerja DPR melalui dunia maya, publik pun terbantu. Para relawan pun diwajibkan mengikuti pelatihan seputar legislatif, belajar menulis, dan melaporkan dalam tiga kali pertemuan. Hingga kini, Jejak Parlemen didukung sebanyak 360 relawan yang sudah mencapai angkatan ke-9 dan it uterus bertambah tiap angkatannya. Setiap angkatan bekerja selama periode satu bulan. Beberapa dari relawan yang telah lulus kuliah turut bergabung kembali untuk menjadi pegawai tetap serta koordinator Jejak Parlemen.

Gerakan ini juga ikut mendorong terciptanya transparansi di lingkungan politik.contoh lain gerakan Kawal Pemilu tahun 2014 yang mengimbangi dan mendorong transparansi kinerja penyelenggara pemilu. Demikian pula gerakan Jejak Parlemen, yang mendorong akun media sosial resmi @DPR_RI untuk lebih transparan mempublikasikan aktivitas anggota DPR. Selama ini, para politisi tidak ada penyeimbang. Namun, dengan perkembangan demokrasi, ada kepentingan kolektif yang dibela melebihi kepentingan pribadi, dan ruang manipulasi itu kian terbatas dengan voluntarisme anakanak muda yang sebenarnya sedang mencoba mencari aktualisasi diri ini. Dalam mewujudkan misinya, jejak parlemen hadir dalam setiap rapat untuk meliput, merekam, dan menyebarkan kembali. Jejak parlemen melibatkan publik untuk turut serta berpartisipasi lewat gerakan relawan. Melalui keterlibatan tersebut, jejak parlemen harus mampu mengkurasi dan mengemas kembali audio/visual rekam jejak setiap anggota parlemen serta kontribusinya dalam ruang-ruang sidang. Tujuan jejak parlemen jelas: agar warga dapat mencermati serta teredukasi atas kinerja wakil rakyatnya.

Pada website jejak parlemen yaitu wikiDPR.org terdapat menu yang informatif yaitu di tampilan awal website pengunjung dapat mencari tahu profil Anggota DPR berdasarkan tempat tinggal dan komisi contoh ketika ingin mencari berdasarkan daerah kota/kabupaten Bali maka akan terlihat daftar anggota DPR daerah pemilihan Bali lengkap dengan partai dan komisinya. Menu selanjutnya adalah berita yang berisi kegiatan-kegiatan yang dilakukan anggota DPR RI, Rangkuman rapat dan bagaimana menjadi relawan. 
Gambar 1 : Infografis review kinerja DPR RI

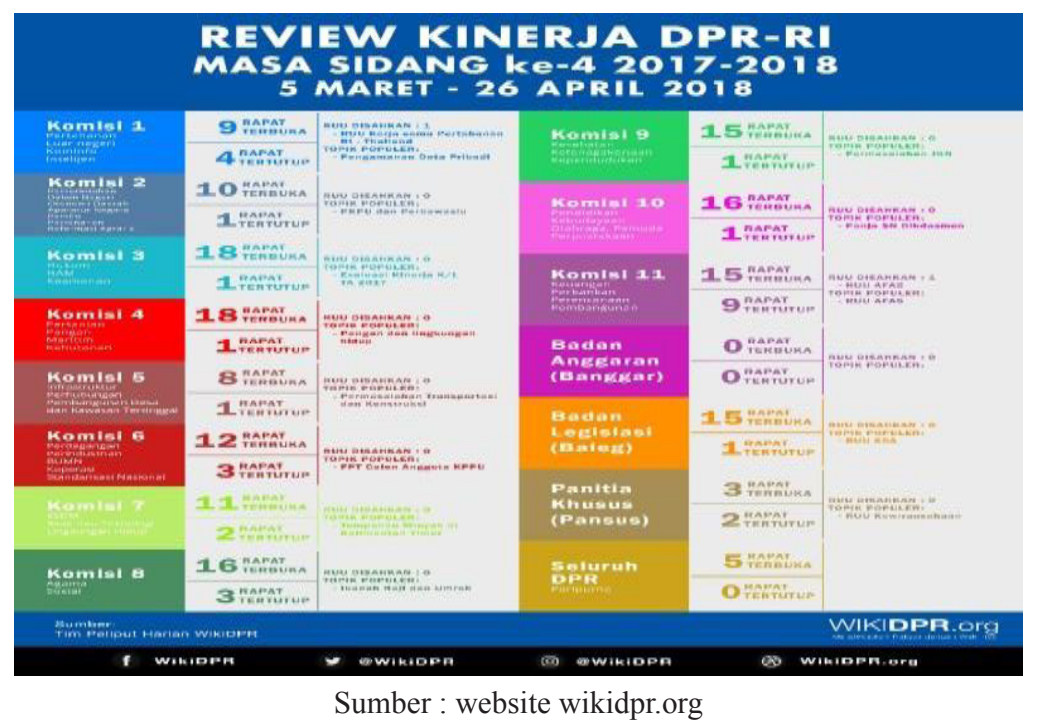

Relawan Jejak Parlemen merupakan generasi muda yang ingin terlibat langsung dalam kegiatan para wakil rakyat di DPR RI. Hal ini sangat menarik karena banyak pengalaman yang mereka dapatkan salah satunya relawan mengungkapkan pengalamannya yang dikutip dalam website wikidpr.org "Saya anak muda haus akan pendidikan politik. WikiDPR adalah pelepas dahaga akan kurangnya pendidikan politik”. Kurnia Gusti (https://wikidpr.org/page/ jadi-relawanAngkatan 2)

\section{Pernyataan tersebut memang berkaitan dengan tugas relawan, yaitu :}

- Meliput dan mempublikasikan seluruh aktivitas-aktivitas wakil rakyat di DPR (seperti rapat komisi, rapat paripurna, rapat alat kelengkapan Dewan, serta wawancara individu terkait dengan kebijakan, misi dan praktiknya) hal ini dipublikasikan dalam bentuk LiveTweet

- Mengupdate informasi dan profil para anggota yang beririsan dengan informasi di LiveTweet masing-masing relawan untuk melengkapi track record mereka (apa saja yang mereka katakan dalam rapat komisi, apa saja pandangan mereka tentang sebuah kasus, apa saja tanggapan mereka mengenai Revisi Undang-Undang, dan lain sebagainya)

Sedangkan kriteria relawannya adalah :

- Para relawan Jejak Parlemen harus memberikan informasi yang transparan mengenai pandangan politik secara jujur kepada sesama relawan dan staff Jejak Parlemen.

- Para relawan Jejak Parlemen harus menekankan sisi netralitas, faktual dan tidak menyuarakan opini subjektif dalam peliputan oleh Jejak Parlemen.

- Relawan Jejak Parlemen harus memperkaya diri dengan pengetahuan dan wawasan seputar isu-isu politik terkini.

Media yang digunakan oleh wiki DPR adalah website www.wikidpr.org dan Twitter@WikiDPR facebook serta instagram@wikiDPR.

\section{Gambar 2. Alur Kinerja WikiDPR}

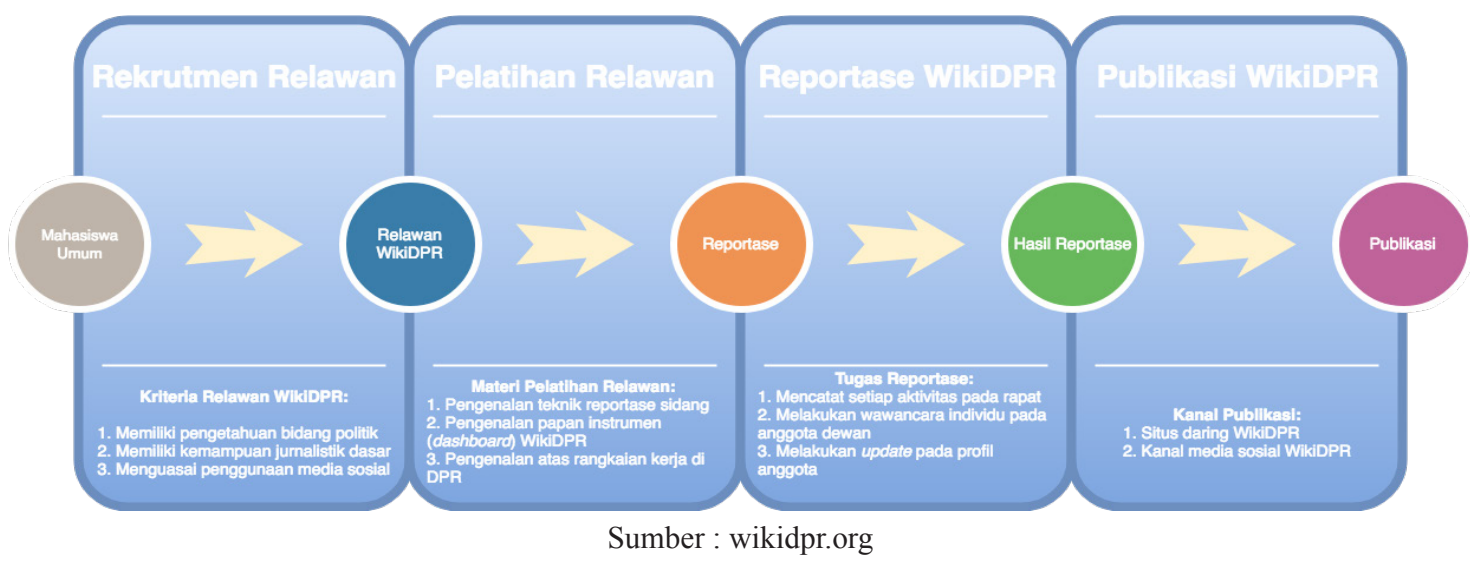

Imaddudin dan Tri Susanto (Pembangunan Partisipasi Politik Generasi Muda melalui Website dan Twitter Jejak Parlemen) 
Tahap 1 : rekrutmen relawan yaitu mahasiswa umum yang memiliki kriteria mengetahui pengetahuan bidang politik, memiliki kemampuan jurnalistik dasar, menguasai penggunaan media sosial.

Tahap 2 : Pelatihan relawan yang meliputi pengenalan teknik reportase sidang, pengenalan paparan instrumen wikidpr, pengenalan atas rangkaian kerja di DPR

Tahap 3 : Reportase jejak parlemen yang bertugas mencatat setiap aktivitas pada rapat, melakukan wawancara individu pada anggota dewan, melakukan update pada profil anggota.

Tahap 4 : Publikasi jejak parlemen melalui kanal online dan media sosial yang bernamakan WikiDPR

\section{PEMBAHASAN}

Menurut Rogers dan Adhikarya (dalam Harun dan Ardianto, 2017:163) kesenjangan efek dapat diperkecil bila strategi komunikasi pembangunan yang dilakukan oleh Jejak Parlemen dalam mengajak partisipasi politik generasi muda adalah merumuskan prinsip-prinsip sebagai berikut:

1. Penggunaan pesan-pesan yang dirancang secara khusus (tailored message) untuk khalayak yang tertentu. Pesan disampaikan jelas yaitu mengajak generasi muda untuk reportase, advokasi, dan inventarisasi data yang berlangsung di DPR, karena Jejak Parlemen bentuk inisiatif masyarakat yang merespons praktik kerja anggota parlemen agar lebih transparan.

2. Pendekatan secara Ceiling Effect dengan mengkomunikasikan pesan-pesan untuk golongan yang tidak dituju, namun tetap berfaedah bagi kelompok khalayak yang hendak dijangkau. Pendekatan Jejak Parlemen berbasis organisasi yang tidak dibentuk oleh pemerintah melainkan lahir dari kesadaran generasi muda untuk ikut ambil bagian berpartisipasi demi kemajuan negeri.

3. Pendekatan Narrow Casting atau melokalisasi proses penyampaian pesan bagi kepentingan khalayak yang dituju. Lokalisasi disini berarti disesuaikan penyampaiannya informasi yang dimaksud dengan situasi kesempatan dimana khalayak berada. Pesan berupa infografis baik berupa laporan sidang, rangkuman dan hasil sidang DPR yang dipublikasikan kepada khalayak.

4. Pemanfaatan saluran tradisional, melalui media yang tidak asing di mata rakyat baik dalam bentuk pertunjukan maupun perkumpulan rakyat yang sejak lama memang berfungsi sebagai saluran pesan yang akrab dengan masyarakat setempat. Pembangunan partisipasi politik melalui Jejak Parlemen yang menggunakan saluran modern yaitu website dan media sosial akan lebih cepat dan tepat jangkauannya.

5. Pengenalan para pemimpin opini di kalangan lapisan masyarakat untuk menolong mengkomunikasikan pesanpesan pembangunan kepada masyarakat setempat. Tentunya wikiDPR sudah melakukan kerjasama yang saling menguntungkan untuk menyebarluaskan hasil sidang agar terciptanya transparansi informasi yang terjadi di DPR RI.

6. Meningkatkan keikutsertaan para agen perubahan politik dari kalangan masyarakat sendiri dan bertugas di lembaga perubahan dan pembangunan partisipasi politik yang beroperasi di kalangan rekan sejawat mereka sendiri. Mahasiswa umum direkrut sebagai relawan untuk terlibat langsung dalam jangka waktu tertentu.

7. Dibentuk serta dibina mekanisme sejak tahap perencanaan sampai evaluasi dengan mengikutsertakan khalayak masyarakat, sebagai pelaku perubahan pembangunan politik. Pembinaan relawan sudah diatur sedemikian rupa seperti yang ditulis diatas tentang alur Jejak Parlemen dalam menjalankan tugas dan fungsinya.

Sedangkan Aspek-aspek penentu terselenggaranya sebuah partisipasi politik, yaitu :

1. Aspek-aspek pendukung pelaksanaan partisipasi politik dipengaruhi oleh pendidikan tinggi yang mampu membentuk partisipasi terkait persoalan-persoalan politik lainnya, baik melalui pembelajaran maupun organisasi dapat meningkatkan kecakapan menganalisa serta menciptakan minat dan kemampuan berpolitik. Relawan Jejak Parlemen memberikan informasi yang transparan dan jujur terkait dengan pandangan politik, yang harus menekankan sisi netralitas, faktual dan tidak menyuarakan opini subjektif dalam peliputan jejak para parlemen, relawan Jejak Parlemen harus memiliki motivasi diri untuk terus menggali pengetahuan dan pemahaman akan seputar isu dan persoalan politik.

2. Aspek-aspek penghambat (alasan) orang lain menghindari kehidupan politik, dikarenakan ketakutan akan konsekuensi negatif dari aktivitas politik, berpartisipasi politik adalah kesia-siaan yang tidak berdampak apapun serta tidak adanya perangsang partisipasi politik karena merasa tidak dihargai ide dan gagasannya.

Kegiatan organisasi Jejak Parlemen memberikan banyak pengalaman di pendidikan politik yaitu mengenai sidang, RUU, Komisi, Partai politik, Tugas Anggota DPR dan menulis serta melaporkan hasil sidang yang dipublikasikan melalui kanal media Jejak Parlemen.

Gerakan pendidikan politik di Indonesia masih sangat minim sehingga pemerintah hendaknya memberikan perhatian khusus sehingga menghasilkan generasi muda yang lebih peduli dengan perkembangan politik di Indonesia. 
Pemerintah perlu mengintensifkan pelaksanaan sosialisasi politik kepada generasi politik. Perlunya kerjasama para pemangku kepentingan (stakeholder) dalam mengoptimalkan peran setiap agen perubahan melalui pendidikan politik yang menyeluruh. Perlunya kepercayaan pada generasi muda dengan diberi kesempatan serta tanggung jawab yang lebih luas dalam ruang publik seperti halnya dilibatkan sebagai anggota partai politik, ataupun organisasi sosial politik lainnya.

\section{KESIMPULAN}

Generasi muda menjadi aset bangsa yang harus dikelola dengan baik, bukan hanya sekedar memahami perkembangan zaman dengan beberapa manfaat dari aspek-aspek seperti politik, ekonomi, sosial budaya, pertahanan atau keamanan serta teknologi informasi, namun tidak dipungkiri setiap pemanfaatannya memiliki tantangan tersendiri. Kolaborasi antara politik serta teknologi ini menjadi perhatian Jejak Parlemen sebagai mediator para relawan untuk mengembangkan potensi serta wawasan dan mengajak para generasi muda untuk lebih mengetahui proses dan perkembangan dunia politik baik para parlemennya maupun sistem dalam politik nya.

Dalam penelitian ini Pengguna media sosial menaruh fokus pada pendidikan politik melalui website dan media sosial twitter@wikiDPR dengan mengajak generasi muda untuk bergabung menjadi relawan yang bertugas mengumpulkan informasi mengenai segala aktifitas yang dilakukan anggota DPR RI dalam menjalankan tugasnya, Relawan yang terdiri dari anak muda ini tidak dibayar dan diberikan masa tugas selama satu bulan.

Media sosial inilah yang digunakan untuk membangun pengetahuan dan wawasan serta kepekaan pada politik bangsa yang sedang berkembang, sehingga pada nantinya generasi muda ini bukan hanya sekedar protes dari segala kebijakan pemerintah, namun bisa memberikan saran maupun action plan. Politik dengan harapannya bukan sekedar tentang kekuasaan melainkan politik bisa membangun kerjasama, politik bisa membentuk pola pikir dalam membangun bangsa ini. Jejak parlemen melalui akunnya@wikiDPR memberikan segala informasi baik biodata para parlemen serta dokumentasi dan analisis terkait perkembangan parlemen sebagai perwakilan rakyat dalam menyelesaikan seluruh aspirasi dan permasalahan rakyatnya. Baik melalui liputan terkait rapat, serta kebijakan-kebijakan pemerintah lainnya.

Hal tersebut diharapkan tidak ada lagi kekeliruan pandangan yang sebelumnya menganggap generasi muda tidak tertarik pada politik. Namun, generasi muda bisa terarah pandangannya terkait partisipasi politik negeri ini. Saran. Perhatian besar juga diarahkan pada generasi muda yang masih memiliki potensi besarnya baik tenaga, intelektualitas, dan waktu untuk berpartisipasi dan berproses di masyarakat terkait dengan persoalan kehidupan politik sehingga tidak hanya aktif dalam menyuarakan pendapat melainkan dapat memberikan gagasan serta solusi konkrit untuk bangsa ini.

\section{DAFTAR PUSTAKA}

BUKU

Budiardjo Miriam. (2008). Dasar Dasar Ilmu Politik, Edisi Revisi. Jakarta: PT. Gramedia Pustaka Utama.

Effendy \& Onong Uchjana. (1987) Peranan Komunikasi Massa Dalam Pembangunan, Yogyakarta: Gadjah Mada University.

Harun, Rochajat \& Elvinaro Ardianto. (2017). Komunikasi Pembangunan Perubahan Sosial. Jakarta : RajaGrafindo Persada.

Kotler, P. a. (2012). Marketing Management 13. New Jersey: Pearson Prentice Hall, Inc.

Mas'oed Mochtar \& Colin Macandrews. (1978). Perbandingan Sistem Politik. Yogyakarta : Gadjah Mada University Press.

Miles, Matthew \& Huberman, A. Michael. (1992) Analisis data Kualitatif: Buku sumber tentang metode-metode baru. Jakarta :UI Press.

Moleong, Lexy. J. (2000). Metodologi Penelitian Kualitatif. Bandung: PT. Remaja Rosdakarya.

Rogers, Everett M \& Shoemaker, F Ployd. (1981). Komunikasi Sambung Rasa, Jakarta : Pustaka Sinar Harapan.

JURNAL

Riaz, Saqib. (2010). Effects of New Media Technologies on Political Communication. Journal of Political Studies, Vol.1 Iss. 2, 2010, h.2.

\section{WAWANCARA}

Hayati, Indah. (2019, 25 November). Personal Interview

\section{PUBLIKASI ELEKTRONIK}

https://wikidpr.org/page/jadi-relawanAngkatan 2 